\title{
Motive Development Training Program for Enhancing the Competitiveness of Semanggi Batik Products
}

\author{
Susi Hardjati*, Muchlisiniyati Safeyah, Kalvin Edo Wahyudi \\ Universitas Pembangunan Nasional “Veteran” Jawa Timur, Indonesia
}

*Corresponding author:

E-mail:

susi_hardjati.adneg@upnjatim.ac.id

\begin{abstract}
This research has two objectives main. First, describe the motive development training program to increase the competitiveness of Semanggi Batik products. The program was intended for the craftsman batik semanggi to join the community self-help group (KSM) Semanggi 2 Sememi Village, Benowo District, Surabaya City. Through this program, it is hoped that the Semanggi Batik motif will be more varied and thus the product competitiveness will increase. The second objective is to analyze the effectiveness of the motive development training program. The effectiveness analysis was carried out by using a descriptive quantitative approach. Data were collected using a questionnaire to 20 respondents. The results of the analysis show three main things. First, the motive development training program is indeed needed by the training participants. This is shown in the perception score of the urgency of the material reaching $82.5 \%$ (very high). Second, it turns out that the ability of the participants in the development of the Semanggi Batik motif is only $30 \%$ (less fortunate). Third, the participants assessed the effectiveness of the training for motive development training at $83.33 \%$ (very high / very effective). Based on this analysis, it can be concluded that the KSM knowledge and skills improvement program in producing semanggi batik is very effective and worthy of being used as a model for batik development in other communities.
\end{abstract}

Keywords: Semanggi batik, program effectiveness, batik motif development

\section{Introduction}

Semanggi (Marsilea Crenata) is a wild plant that is often found in watery areas such as rice fields, swamps, riversides, and lakes. The clover plant is well known by the people of Indonesia and is often processed as a vegetable such as Pecel Semanggi which is a typical food of the city of Surabaya. Morphologically, clover has four leaflets with an average length of $2.5 \mathrm{~cm}$ and a width of 2,3 cm. The leaves are thin and soft, dark green (www.greeners.co). Judging from its shape, clover leaves do have their uniqueness. The uniqueness of the shape of the clover leaves is what inspired the emergence of batik with a semanggi leaf motif, or better known as Semanggi Batik in Sememi Village, Benowo District, Surabaya City. So far, Benowo District is known as a producer of Semanggi Pecel. This means that the clover plant is very well known by the people in Benowo District. So, it is only natural that later batik appears with a cloverleaf motif.

Semanggi Batik is one of the original and typical batik which has become an icon of Sememi Village, Benowo District, Surabaya City. As the original batik of Surabaya City, it needs serious attention from the Surabaya City Government and other elements of society to preserve or maintain the existence of Semanggi Batik. Besides, the emergence of Semanggi Batik was encouraged by the desire of PKK RW members 01 Jalan Sememi Jaya Gang 8 Sememi Village, Benowo District, Surabaya City to improve the family economy. This desire was later realized by establishing the

How to cite:

Hardjati, S., Safeyah, M., Wahyudi, K. E. (2021). Motive development training program for enhancing the competitiveness of Semanggi batik products. $5^{\text {th }}$ International Seminar of Research Month 2020. NST Proceedings. pages 358-362. doi: 10.11594/ nstp.2021.0954 
Semanggi 2 Community Self-Help Group (KSM). The reason for the economic improvement of this family also needs serious attention through the empowerment of Semanggi Batik craftsmen. The hope is, with empowerment, Semanggi Batik craftsmen will increase their competence, increase the competitiveness of their batik products, and increase their welfare.

Semanggi Batik craftsmen need serious attention in the form of empowerment. The research results of Hardjati et al. (2019) show that semanggi batik has low competitiveness. This is indicated by the existence of several problems in the production of semanggi batik. First, the problem is related to the production of semanggi batik which still relies on orders. This means that the production of semanggi batik cannot be done in a ready stock manner and the production scale is still small. Second, there is a problem related to traditional equipment. The third problem is the limited marketing ability of craftsmen. Besides, the production of semanggi batik has stopped operating for 3 years.

Further research results from Hardjati et al. (2020) also reveal that Semanggi Batik has the strength, namely the iconic distinctive motif, namely the semanggi leaf. This distinctive motif is certainly an identity as well as a special attraction for semanggi batik. The results of our team's assessment at the time of observation, the existing semanggi batik motifs are already good. However, analyzing some of the products that have been produced by the craftsmen, the semaggi batik motifs that have been produced seem monotonous. and less varied. For this reason, we think that there is a need for training in the development of motifs for semanggi batik craftsmen so that the semanggi batik motifs can be more varied. This more varied motive will of course increase the competitiveness of semanggi batik products. This is what motivated our team to design a community service program, namely training in the development of semanggi batik motifs through the Community Research Result Implementation (PIHAT) scheme of the Universitas Pembangunan Nasional “Veteran” Jawa Timur.

The quality of the motif is one of the most important things in increasing the competitiveness of batik products. Batik that has distinctive/original, unique, and attractive motifs will certainly have high competitiveness. For that, batik craftsmen must think about the development of batik motifs, so that their competitiveness increases. Likewise, Semanggi Batik motifs, also need to be developed so that the competitiveness of Semanggi Batik Products can be further enhanced.

The importance of the development of batik motifs is shown from the results of research by Poerwanto and Sukirno (2012) that the innovation of the Pesisiran Batik motifs, especially in the Pekalongan area, is closely related to the growth of the fashion, design, and craft industries. This means that innovative batik motifs will certainly create opportunities for other industries such as fashion, design, and crafts. Another opinion, namely by Subadyo (2016) states that the typical Bondowoso batik motif has problems, namely the lack of existing decorative motifs (motifs). Therefore, it is necessary to provide supplies and training for prospective designers from partners to develop the types of Bondowoso batik motifs (contemporary, vernacular, and conventional traditions) with a backing on the exploration of the cultural potential and the landscape environment.

The importance of developing batik motifs was also conveyed by Suliyati and Yuliati (2019) who argued that the efforts of various parties, both batik craftsmen, the government, and Semarang community members in developing Semarang batik motifs, have yielded positive results and effects, namely increasing the thematic cultural tourism destinations of Kampung Batik. and Kampung Djadoel. The research results above show that the development of batik motifs is proven to increase competitiveness and excellent business opportunities in the future. Thus, to increase the competitiveness of Semanggi Batik products, a motive development training program is needed.

\section{Description Program and Analysis}

The semanggi batik motif development training program begins with the following steps:

1. Finalizing the formation of a community service team, involving students. There are four students involved in the training program. The details are two people from the 
Public Administration Study Program and two people from the Visual Communication Design Study Program.

2. Coordinate with KSM Semanggi 2 administrators to prepare for the event. This coordination is important to do to ensure the willingness of the management and members of KSM Semanggi 2 in the training. In addition, coordination is carried out for permits for the place to be used as a training location.

3. Compiling material in the form of draft training modules and presentation materials.

4. Prepare the needs of the event, such as infrastructure for the COVID 19 preventive health protocol, decorations, training facilities, administration and consumption.

The Semanggi Batik motif development training program was conducted on September 13, 2020, at 07.30 - 12.00 WIB. The location of the training is in the Nurhakim Building, Al Mu'awanah Islamic Elementary School, Sememi Village, Benowo District, Surabaya City. The training was attended by 20 craftsmen/members of KSM Semanggi 2. Given the COVID 19 pandemic, training activities for the development of a semanggi batik motif were carried out by prioritizing health protocols such as the mandatory application of masks, giving masks to participants, measuring body temperature, washing hands / giving hand sanitizers, and controlling the distance between participants. The training material for the development of semanggi batik motifs was delivered directly by the PIHAT team. The material for developing the semanggi batik motif is described below (quoted from the draft module).

\section{Jagad semanggi batik motif}

The batik motif is inspired by the original shape of the cloverleaf with 4 strands and 4 main elements from nature, namely water, earth, wind, and fire. Each side of the cloverleaf symbolizes these four elements to remind people of complementary lives and create beauty. The ornament that is in the middle between the 4 kinds of elements serves as a counterweight.

\section{King semanggi batik motif}

The batik motif was adopted from clover leaves. The pattern of the cloverleaf represents luxury as well as luck. The cloverleaf used is a 4-leaf clover, which means good luck.

\section{The semanggi wheel batik motif}

This batik motif is inspired by the shape of a cloverleaf combined with the shape of a windmill that seems to spin and produces a breeze from the cloverleaf. The style is simple but produces a dazzling beauty.

Through training in developing semanggi batik designs with three development motives, namely semanggi universe batik, semanggi king batik, and semanggi mill batik, the semanggi batik motifs produced by KSM Semanggi 2 will be more varied. With a variety of motives, it is expected that the competitiveness of batik products will increase. The increased competitiveness is expected to also increase the sales volume and production of semanggi batik. Finally, it is hoped that the welfare of the craftsmen will increase.

\section{Analysis of the effectiveness of the training program}

We also analyzed the BatiK Semanggi motif development training program to measure its effectiveness. Effectiveness is measured by 3 variables. First, is the participant's perception variable on the urgency of the training material. Namely to measure how high the participants rated the importance of the training material. Second, is the variable of the participant's ability to develop batik motifs before the training. The third is the participant's assessment of the semanggi batik motif development training program. The effectiveness analysis was carried out by using a descriptive quantitative approach. Data were collected using a questionnaire to 20 respondents with 
many questions. Each question is given a choice of answers with a scoring category: 1, 2, 3, 4, 5 . The analysis was carried out by calculating the minimum value, maximum value, recapitulation value, percentage of the recapitulation score, and determining the assessment category. There are 5 categories of assessment, namely: 0-19 = very low; 20-39 = low; 40-59 = enough; 60-79 high; 80-100 = very high. The calculations are described below.

\section{Analysis of participants' perceptions of the urgency of the batik motif development training material}

Min value $=1 \mathrm{X} 1 \mathrm{X} 20=20$

Max value $=5 \mathrm{X} 1 \mathrm{X} 20=100$

Recapitulation score $=260$

Percentage $=(($ recapitulation score $-\min$ score $):(\max$ score - min score $)) \mathrm{X} 100$

Percentage $=((86-20):(100-20)) \times 100=$

(66: 80 ) X $100=82.5 \%$ (very high category)

This means that the training participants think that the training material for the development of batik motifs is very important to increase product competitiveness.

\section{Analyze the participants' abilities in developing semanggi batik motifs}

Min value $=1 \mathrm{X} 1 \mathrm{X} 20=20$

Max value $=5 \mathrm{X} 1 \mathrm{X} 20=100$

Recapitulation score $=44$

Percentage $=(($ recapitulation score $-\min$ score $):(\max$ score - min score $)) \mathrm{X} 100$

Percentage $=((44-20):(100-20)) \times 100=$

(24: 80 ) X $100=30 \%$ (low category)

This means that the training participants have a low ability in developing semanggi batik motif designs.

\section{The effectiveness of the batik motif development training program}

Min value $=1 \mathrm{X} 3 \mathrm{X} 20=60$

Max value $=5 \times 3 \times 20=300$

Recapitulation score $=260$

Percentage $=(($ recapitulation score $-\min$ score $):(\max$ score - min score $)) \mathrm{X} 100$

Percentage $=((260-60):(300-60)) \times 100=$

(200: 240 ) X $100=83.33 \%$ (very high category)

This means that the training participants considered that the training to develop batik motifs was very effective in increasing the variety of existing semanggi batik motifs.

\section{Conclusion}

Variative and innovative motives will increase the competitiveness of batik products, including Batik Semanggi. For this reason, a training program for the development of a semanggi batik motif was held with three new development motives, namely the semanggi universe batik, the semanggi king batik, and the semanggi pinwheel batik. The motive development training was also analyzed for its effectiveness. The results of the analysis show three main assessments. First, the motive development training program is indeed needed by the training participants. This is shown in the participant's perception score of the urgency of the training material reaching $82.5 \%$ (very high category). Second, it turns out that the ability of the participants in the development of the 
Semanggi Batik motif is only 30\% (low category). Third, the participants assessed the effectiveness of the training for motive development training at $83.33 \%$ (very high / very effective category). Based on this analysis, it can be concluded that the KSM knowledge and skills improvement program in producing semanggi batik is very effective and worthy of being used as a model for batik development in other communities.

\section{References}

Hardjati, S., Prathama, A., \& Wahyudi, K. E. (2019). Potret pemberdayaan perajin batik semanggi di kota surabaya dalam perspektif good governance. Prosiding Konferensi Nasional Ilmu Administrasi (KNIA) 3.0 STIA LAN Bandung Tahun 2019. http://180.250.247.102/conference/index.php/knia/article/view/171

Hardjati, S., Prathama, A., \& Wahyudi, K. E. (2020). Pemetaan lingkungan internal - eksternal dalam upaya pemberdayaan pengrajin Batik Semanggi Kota Surabaya. JKMP: Jurnal Kebijakan dan Manajemen Publik, 8, 16-22.

https://www.greeners.co/flora-fauna/semanggi-legenda-sang-pembawa-keberuntungan/

Poerwanto \& Sukirno, Z. L. (2012). Inovasi produk dan motif seni batik pesisiran sebagai basis pengembangan industri kreatif dan kampung wisata minat khusus. Jurnal Al-Azhar Indonesia Seri Pranata Sosial, 1(4), 115-120.

Subadyo, H. A. T. (2016). Pengembangan motif batik Bondowoso sebagai ekspresi akulturasi budaya. Jurnal ABDIMAS Unmer Malang, 1(1), 114-119.

Suliyati, T \& Yuliati, D. (2019). Pengembangan motif batik semarang untuk penguatan identitas budaya Semarang. Jurnal Sejarah Citra Lekha, 4(1), 61-73. 